\title{
Maintaining the Diversity of California's Municipal Forests
}

\author{
Robert N. Muller and Carol Bornstein
}

\begin{abstract}
Policies to promote urban forest diversity were assessed in 49 California, U.S. municipalities through a short questionnaire, followed by evaluation of street tree inventories and approved planting lists. While the majority of respondents (82\%) indicated maintaining species diversity was an objective in managing their municipal forest, fewer than half of those responding positively $(48 \%)$ had codified the objective in an actual urban forest management plan. Protecting against invasive species was an objective for a minority of communities (24\%). Street tree inventories, provided by 18 respondents, indicated a high existing diversity within the communities of the state of California (avg. 185 species per community; range 95-408). In communities where both inventories and approved planting lists could be compared directly, the number of approved species for future planting was $29 \%$ of the number of species in the existing inventory. This suggests that the future diversity of California's urban forests may be at risk. In order to improve diversity of their municipal forests, it is suggested communities retain an experimental approach to evaluating new species, build productive collaborations with all stakeholders as well as other communities, and develop outreach opportunities to enhance public awareness of the multiple values of a diverse urban forest.

Key Words. California; Diversity; Invasive Species; Municipal Forest; Urban Forest.
\end{abstract}

In both natural and urban ecosystems, species diversity has been recognized as an important attribute of stability, providing resistance to diseases, pests, and environmental oscillations. In natural settings, diversity has long been understood to be greatest in benign environments (Huston 1979), and is a product of various ecological interactions (Willis and Whittaker 2002). However, in urban environments these ecological rules do not apply and diversity is primarily a function of human habitat modification - the product of individuals and institutions whose collective actions have created the landscape we call the urban forest.

In metropolitan settings, the benefits of a healthy urban forest are multiple and include several tangible benefits of environmental modification (Nowak and Dwyer 2007). Among these direct environmental benefits are cooling the urban heat island (energy conservation), improved air quality, reduced runoff, noise reduction, and improved wildlife habitat (Gilbert 1991; McPherson et al. 1997). However, healthy urban forests also provide important benefits of social well-being for those who live in urban settings (Dwyer et al. 1992). These less tangible but equally important benefits include desirable habitat (translated as increased real estate values), improved health and well-being of residents, a greater sense of community, reduced domestic violence, and increased economic development (Sullivan and Kuo 1996; Kuo 2003; Elmendorf 2008; Heidt and Neef 2008; Kielbaso 2008). Many of these qualities have been translated into financial terms, which suggest significant economic incentives for maintaining a healthy urban forest (Tyrväinena and Miettinen 2000).

Most evaluations have considered urban forests assets whose benefits are solely based upon the number and size of trees in the urban landscape [e.g., cooling the urban heat island or moderating stormwater runoff (e.g., McPherson et al. 1997)]. Benefits of diversity in the composition of an urban forest are not often considered, but if discussed, usually follow ecological reasoning, noting the benefits for a sustained resource in the face of diseases, pests, or significant environmental change (Botkin and Talbot 1992; Clark et al. 1997; Saebo et al. 2005). These are important and real values. High species diversity ensures maximal protection from the impacts of environmental stress, pests, and pathogens, thereby enhancing overall stability (Frank and McNaughton 1991). In natural settings, increased diversity is correlated with increased system-wide stability (Schulze and Mooney 1993), and one might expect the same to hold for managed urban forests, as well.

In the special case of urban forests, the human element adds additional dimensions to the importance of diversity. In the view of some, maintaining a diverse urban forest contributes to preserving global biodiversity of both species and genetic resources (Löfvenhaft et al. 2002; Heynen 2003; Chen and Jim 2008). A diverse urban forest also provides an array of phenological events, such that leaf out, flowering, fruiting, and leaf fall occur throughout the growing season, which is virtually year-around in much of California. Additionally, high diversity provides numerous textures and colors in the landscape and silhouettes on the skyline. Taken together, these attributes of the urban forest contribute to an emotional sense of well-being that translates into reduced stress (Ulrich 1979), and increased rates of recovery from surgery (Ulrich 1984; Ulrich et al. 1991). These beneficial effects of nature on physical and mental health have been documented in hospitals, prisons, and homes (Kaplan 1995). Trees in the urban forest inspire deep emotional feelings that border on the spiritual (Dwyer et al. 1991), and a diverse assemblage of species within the urban forest enhances that perception by creating individually identifiable trees within the broader matrix.

Another element of diversity in the urban forest is often overlooked. During European exploration of the world in the 18th and 19th Centuries, exotic plants (including many trees) were collected as scientific curiosities and often served as an entree 
to distant lands. Today, those exotic curiosities and many subsequent introductions grace our urban forests and provide tangible connections to the ecosystems and cultures that make up our world. Yet, the origin, ecological characteristics, and cultural uses of species in our urban forests are rarely included in education programs. Knowing the Australian tea tree (Leptospermum laevigatum) was a reputed source of vitamin $\mathrm{C}$ used by Captain Cook to prevent scurvy in his crew brings an appreciation of world history as well as health benefits. Similarly, knowledge of present-day use of locust bean gum, derived from the carob tree (Ceratonia siliqua), as a thickening and emulsifying agent in processed foods ranging from sausage products to ice cream (Coppen 1995) fosters an understanding of the continued, and often unappreciated, dependence of our own culture on plant products. In this context, urban forests can be viewed as "conservatories of the world," providing a glimpse into the varieties of trees that peoples of the world see and use in their daily lives. These same conservatories can provide opportunity for educational messages regarding protection of threatened species. For example, the seed of ivory-nut palms (Phytelephas spp.) has been used as a substitute for elephant ivory (Clay and Clement 1993).

Urban forest diversity has not been comprehensively evaluated and the existing studies often come to contradictory conclusions (see, for example, McKinney 2002; Kühn 2004; Wania et al. 2004). Further, no longitudinal studies of diversity change over time have been conducted. Anecdotal evidence in one Southern California metropolitan area suggests that diversity may in fact be falling (Muller, unpublished data). Four editions of Trees of Santa Barbara have provided a species inventory for the metropolitan area that includes Montecito, Santa Barbara, and Goleta. During the period between the last two editions (Muller et al. 1974; and Muller and Haller 2005), the number of trees in the municipal forest (streets, parks, and publicly accessible gardens) declined by over $10 \%$ (from 470 to 420 ). While specific reasons for the loss of each species are not always known, multiple factors likely contributed to the overall decline, including lack of proper maintenance (i.e., appropriate pruning or watering), drought, disease, and development. Another factor at play is that entrepreneurs and botanical institutions in California have not maintained historical traditions of seeking new introductions for evaluation. This is not surprising considering the significant costs associated with such endeavors and is most evident in the lack of diverse and unusual inventories in retail nurseries (Zipperer 2008). Plant identification courses required of students majoring in horticulture or landscape architecture tend to favor the more common, easier to find species, thereby reinforcing the familiar. Public intolerance of trees that produce messy litter or have sidewalk-disrupting root systems is yet another factor. Finally, some of those species that were lost may simply have been inappropriate for Santa Barbara's climate. Horticulture, after all, is a continuing experiment.

The experiences in Santa Barbara raise serious questions about the motivation and long-term ability of communities to maintain high diversity in their municipal forest. Do communities value species diversity in their municipal forest? Are those values formally codified in a community's urban forest management plan? Do communities help ensure the diversity of their municipal forest through their list of approved trees for planting along streets and in public places? To evaluate these and other questions, a questionnaire was designed and distributed to determine policies towards species diversity in the municipal forest and to determine limitations in maintaining diversity of these plantings. As part of this evaluation, planting lists of species approved for street tree planting and, where available, inventories of existing street trees for comparison were solicited. The focus of this evaluation was the street tree component of each community's municipal forest. The municipal forest encompasses both street trees and parks, and is that portion of the urban forest that community agencies can most immediately influence through ordinance, planting programs, and maintenance. Since street trees account for the majority of the municipal forest, policies directed towards street trees will likely have the greatest and most immediate effects on urban forest diversity.

\section{METHODS}

A short questionnaire was sent to all 169 Tree City USA municipalities in California, with repeat requests to non-respondents sent five weeks after the initial inquiry. In all, 49 questionnaires were returned (Table 1) for a response rate of $29 \%$. The survey was designed as an initial inquiry into municipal policies/practices regarding diversity and asked questions regarding management of the municipal forest (Appendix). The combination of closed- and open-format questions allowed the collection of readily analyzed data while encouraging respondents to provide additional insights into their particular situation. While the question regarding invasive exotic species is tangential to the central thrust of the survey on attitudes towards diversity, it is a critical element of how a responsible community manages its urban forest.

The questionnaire also asked respondents to provide copies of "acceptable species" for street tree plantings and, if available, their street tree inventory as well. Forty-two municipalities provided lists of approved species and $18 \mathrm{mu}-$ nicipalities provided their most recent inventory. Seventeen of these communities provided both approved planting lists and their most recent inventory. For tabulation purposes, cultivars were not considered to be distinct from the parent taxon although known hybrids were maintained as distinct taxa.

Survey data were tabulated and are presented as the number of respondents answering a question affirmatively or negatively. Inventory lists were summarized by number of taxa represented. For correlation purposes, municipality population and per capita income were obtained from the U.S. Census Bureau, State and County QuickFacts (U.S. Census Bureau 2008). Population estimates were for 2006 and Per Capita Income estimates were for 1999. Correlation analysis was conducted between street tree diversity (number of taxa present) and independent variables (population, per capita income) as simple linear regression, with significance accepted at $P<0.05$.

Tree City USA recognizes municipalities that have made a commitment to their urban forest by maintaining: 1) a tree board or department, 2) a tree care ordinance, 3) a community forestry program with an annual budget of at least USD \$2 per capita, and 4) an Arbor Day observance and proclamation.

\section{RESULTS}

The purpose of the survey was to determine policies and practices within California municipalities designated as Tree City USA regarding diversity in their urban forest. Of the 49 respondents, $40(82 \%)$ indicated maintaining species diversity was an objective in managing their urban forest (Table 2). However, fewer than half of those responding affirmatively $(19 ; 48 \%)$ indicated 
the goal of maintaining a diverse urban forest was codified in an actual management plan, usually as part of the overall community urban forest management plan. As might be anticipated, the personnel involved in developing a diversity management plan varied significantly among municipalities, ranging from the urban forester alone to a group consisting of the urban forester, parks and recreation commissioner, and parks commission. In a few cases, a broader group composed of the mayor, council member(s), planning commissioner, parks commissioner, city manager, public services director, urban forester, and the pub-

Table 1. California, U.S., communities responding to survey and providing approved planting list and street tree inventory.

\begin{tabular}{|c|c|c|c|c|}
\hline Community & Population $^{\mathrm{z}}$ & $\begin{array}{l}\text { Per Capita } \\
\text { Income }(\$)^{z}\end{array}$ & $\begin{array}{l}\text { \# Planting } \\
\text { List Species }\end{array}$ & $\begin{array}{l}\text { \# Inventory } \\
\text { Species }\end{array}$ \\
\hline Anaheim & 334,425 & 18,266 & 51 & 357 \\
\hline Arcadia & 53,054 & 28,400 & 56 & \\
\hline Burbank & 104,317 & 25,713 & 76 & 176 \\
\hline Burlingame & 27,573 & 43,565 & 38 & 116 \\
\hline Carlsbad & 92,928 & 34,863 & 50 & \\
\hline Chula Vista & 212,756 & 18,556 & 37 & 134 \\
\hline Claremont & 35,103 & 28,843 & 71 & 254 \\
\hline Coronado & 22,845 & 34,656 & 23 & \\
\hline Costa Mesa & 109,809 & 23,342 & 55 & \\
\hline Davis & 60,964 & 22,937 & 68 & 156 \\
\hline Downey & 109,376 & 18,197 & & 199 \\
\hline El Cajon & 91,756 & 16,698 & 24 & 122 \\
\hline El Segundo & 16,282 & 33,996 & 32 & \\
\hline Folsom & 66,123 & 30,210 & 87 & \\
\hline Glendale & 199,463 & 22,227 & 103 & 320 \\
\hline Glendora & 50,370 & 25,993 & 32 & 165 \\
\hline Goleta & 55,204 & 28,890 & 36 & \\
\hline Hayward & 140,606 & 19,695 & 15 & 139 \\
\hline Huntington Beach & 194,436 & 31,964 & 95 & \\
\hline La Mesa & 53,043 & 22,372 & 16 & \\
\hline La Puente & 41,526 & 11,336 & 25 & 43 \\
\hline Lodi & 62,451 & 18,719 & 45 & \\
\hline Milpitas & 64,292 & 27,823 & 44 & 95 \\
\hline Modesto & 205,721 & 17,797 & & 245 \\
\hline Newark & 41,891 & 23,641 & 51 & \\
\hline Newport Beach & 80,006 & 63,015 & 77 & 241 \\
\hline Oceanside & 161,029 & 20,329 & 55 & \\
\hline Pasadena & 141,133 & 28,186 & & \\
\hline Pomona & 154,271 & 13,336 & 30 & 101 \\
\hline Riverside & 293,761 & 17,882 & 95 & \\
\hline Roseville & 107,158 & 27,021 & 87 & \\
\hline San Dimas & 35,714 & 28,321 & 40 & \\
\hline Santa Barbara & 85,681 & 26,466 & 105 & $408^{y}$ \\
\hline Santa Cruz & 54,778 & 25,758 & 33 & \\
\hline Santa Maria & 84,712 & 13,780 & & \\
\hline Santa Monica & 88,050 & 42,874 & & 224 \\
\hline Santa Rosa & 154,212 & 24,495 & 41 & \\
\hline Santee & 52,530 & 21,311 & 56 & 159 \\
\hline Saratoga & 29,843 & 65,400 & 23 & \\
\hline Sierra Madre & 10,874 & 41,104 & 49 & 161 \\
\hline Simi Valley & 30,045 & 26,586 & 53 & \\
\hline Sunnyvale & 130,519 & 36,524 & 28 & 199 \\
\hline Thousand Oaks & 124,207 & 43,047 & 32 & 170 \\
\hline Turlock & 55,810 & 16,844 & 12 & \\
\hline Union City & 69,477 & 22,890 & 28 & 143 \\
\hline West Covina & 107,745 & 19,342 & & \\
\hline West Sacramento & 44,162 & 15,245 & 50 & \\
\hline Yuba City & 36,578 & 15,928 & 20 & \\
\hline
\end{tabular}

${ }^{\mathrm{z}}$ Population and per capita income were obtained from the U.S. Census Bureau (2008) and represent data for 2000 and 1999, respectively.

${ }^{\mathrm{y}}$ This is lower than the number of trees in Santa Barbara cited previously as the inventory includes strictly street trees in the municipality of Santa Barbara and includes neither trees in parks and public gardens, nor those in the broader metropolitan area including Montecito and Goleta. lic at large was represented in formulating the plan. Six of the 19 municipalities with formalized diversity plans indicated that their plans included steps to address potentially invasive species. However, an additional six municipalities indicated they had invasive species plans in place without a plan to increase diversity. Although the questionnaire did not specifically ask about planting of native species, one municipality indicated its overall urban forest plan was to plant California native species in order to encourage food sources and nesting sites for native birds.

Thirty-nine of the 49 respondents $(80 \%)$ indicated an inventory of street trees was in place; however, several expressed regret that the inventory was long out of date (10-20 years old). Responses varied as to how often the inventory was updated. Twenty-three of the 39 municipalities with inventories (59\%) indicated these were updated at frequencies of one year or less, suggesting that planting and removal were regularly updated in the inventory. An additional six respondents indicated that inventories were updated on a 10-20 year basis, suggesting that inventories were static until a new one was conducted. Most of the respondents who did not have an existing inventory cited lack of financial resources as the primary reason. Only one of the 39 respondents who maintained a street tree inventory made it available online.

Forty-five of the 49 respondents $(92 \%)$ indicated they maintained lists of acceptable species for planting on public streets (medians and parkways). The number of approved species among the 42 communities providing such a list averaged 49 (range 12-105). However, the number of species making up the combined list of approved species from all 42 communities was significantly greater - 309 (Table 3 ). Relatively few species were common to planting lists of a large proportion of those communities (Figure 1). In total, only six species were found on planting lists of more than $75 \%$ of the responding communities. In contrast, almost two-thirds of the species (198) were found on the approved lists of five or fewer communities (Figure 1).

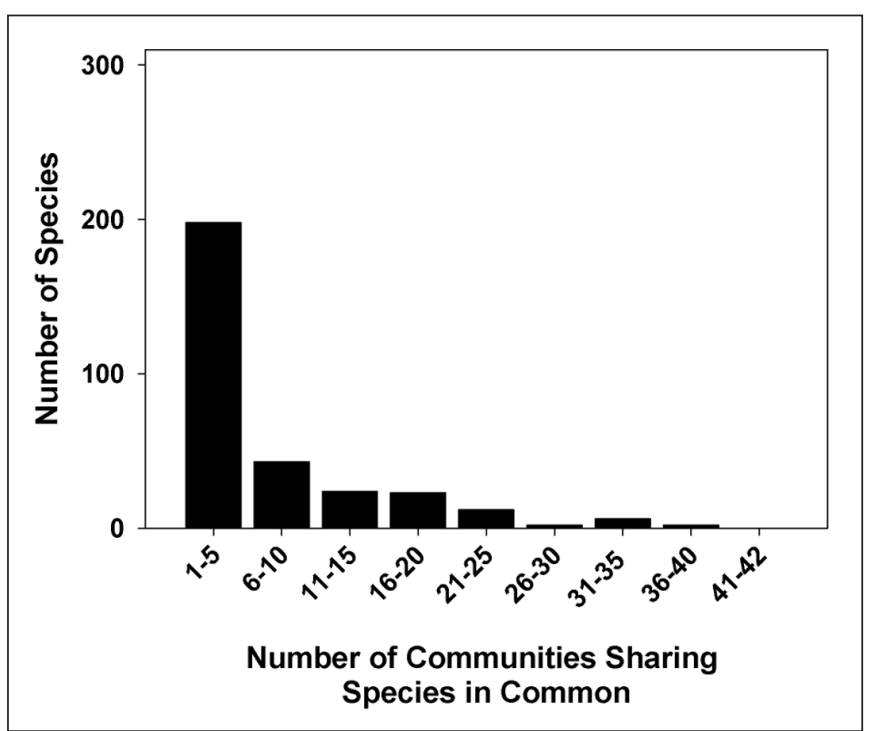

Figure 1. Frequency of species occurrence on approved street tree planting lists of 42 California communities. Of the 309 species on the combined approved planting lists, most were approved by only a few of the responding communities. For instance, 198 of those species were found on the planting lists of five or fewer communities. 
Table 2. Survey responses: policies and practices regarding diversity in the municipal forest of California Tree City USA communities.

\begin{tabular}{ll}
\hline $\begin{array}{l}\text { Number of cities responding } \\
\text { Community has a goal of increasing }\end{array}$ & 49 \\
diversity of urban forest & $40(82 \%)$ \\
Community's goal of urban forest diversity & $19(48 \%)$ \\
$\quad$ is codified in a management plan & $6(32 \%)^{\mathrm{z}}$ \\
Management plan addresses invasive & \\
exotic species & $39(80 \%)$ \\
Community maintains a street tree inventory & $23(59 \%)$ \\
Inventory is updated at intervals less & $6(8 \%)^{y}$ \\
than one year & $45(92 \%)$ \\
Inventory is updated at intervals of 10-20 years & \\
Community maintains a list of acceptable trees & \\
for planting on streets & \\
& \\
&
\end{tabular}

Street tree inventories were provided by 18 respondents. On average, responding communities contained 188 species (range 43408 ) in their urban forest. While the high end of this range (408) seems extraordinary, two additional communities had inventories containing over 300 species. There was no significant correlation between inventory diversity and either community population or per capita income $(P>0.05)$. The combined inventories of all 18 communities included 632 species (Table 2). As in the planting lists, a small proportion of the species $(72 ; 11 \%)$ were found in $75 \%$ of the communities (14 or more), while over half of the species $(351 ; 56 \%)$ were found in three communities or fewer. Interestingly, there was a strong correlation between number of species in a community's inventory and the number of species on its approved planting list $\left(r^{2}=0.81 ; P<0.01\right)$. On average, the number of species on the approved planting lists of individual communities was $29 \%$ of the existing street tree inventory (range 10-58).

In so far as could be determined from titles of respondents, all were employees of the municipality and had direct responsibility for management of the municipal forest. While many were certified arborists and carried the title of Urban Forester, others may have had responsibility for street tree management included within a broader mandate (e.g., Public Works Supervisor).

Table 3. Summary of species on the combined approved planting lists and street tree inventories of California, U.S., communities responding.

\begin{tabular}{cl}
\hline & Number of Species \\
\hline Approved Planting Lists $^{z}$ & 309 \\
Native Species & $30(9.7 \%)$ \\
Invasive Species & $12(3.9 \%)$ \\
Street Tree Inventories & \\
Native Species & 632 \\
Invasive Species & $50(7.9 \%)$ \\
\hline
\end{tabular}

${ }^{\mathrm{z}}$ Approved planting lists were provided by 42 communities; street tree inventories were provided by 18 communities.

${ }^{y}$ Invasive species are defined by the California Invasive Plant Inventory Database (Cal-IPC 2009).

\section{Municipal Policies Toward Diversity}

The concept of diversity has gained currency in many realms of life. A large proportion of respondents (82\%) indicated that maintaining diversity was an objective in managing their urban forests. Goals are easy to establish, whereas translating objective into action is more difficult. Fewer than half of those municipalities indicating a desire to maintain diversity had actually codified their objective into a concrete management plan. Ironically, codification in a management plan did not translate into increased diversity on the ground. Although there was a slight trend towards higher diversity in inventories and planting lists of municipalities with an objective of "diversifying their tree population," this was not statistically significant $(P>0.05)$.

Had they been asked, any of the professionals surveyed would likely have acknowledged an accurate inventory is a critical tool in effective management of their urban forest. Yet, $20 \%$ of communities surveyed did not maintain a municipal forest inventory, and nine of the 39 with an inventory had not updated theirs within the past five years. Maintaining an accurate inventory is the first step in maintaining diversity of a municipality's urban forest; however, it appears that many communities do not have this tool at their disposal.

\section{Municipal Policies Toward Invasive Species}

While concern for introduction of invasive species in urban forests has been expressed in some discussions (Alvey 2006; Avalos et al. 2006), this has not permeated urban forest planning to the extent diversity has. At issue is the possibility that species planted for horticultural use escape the bounds of the managed landscape and significantly alter adjacent native habitats. Only 12 of the 48 respondents $(25 \%)$ have urban forest management plans that address the issue of invasive species. However, a critical comparison of all approved planting lists (from 42 communities) with lists of known invasive species (Cal-IPC 2009) suggest there is considerable room for improvement. While no species of "high" invasive capacity were listed, four species of "moderate" capacity had been approved, including Eucalyptus globulus (approved by 1 community), Myoporum laetum (1 community), Sapium sebiferum (23), and Washingtonia robusta (17). An additional eight species of "limited" invasive capacity were also listed: Acacia melanoxylon (3), Eucalyptus camaldulensis (1), Olea europaea (9), Phoenix canariensis (6), Prunus cerasifera (25), Robinia pseudoacacia (3), Schinus molle (10), and Schinus terebinthefolius (4). While the extent to which these species were evaluated for potential invasiveness in the context of the individual communities that listed them is unknown (e.g., geographic location and local habitat), it appears this aspect of considering a species' appropriateness is often overlooked. Seven of the 12 communities with management plans that address invasive species provided approved planting lists. Surprisingly, all but one of those communities approved the planting of at least one of the above invasive species listed by Cal-IPC (2009), and one community approved the use of seven species from the same list. This data suggests the need for more rigorous evaluation of potentially invasive species at the local level, along with improved public awareness (Reichard 1997; Reichard and White 2001).

Genetic pollution of locally indigenous native species is perhaps equally important and must be addressed when considering diversity of the urban forest. Planting near-relatives adjacent

\section{DISCUSSION}


to existing stands of native trees may lead to genetic contamination that will likely have lasting impacts. As a case in point, while London plane tree (Platanus $\times$ acerifolia) itself does not exhibit invasive characteristics, genetic interchange has seriously compromised native California sycamore (Platanus racemo$s a)$ populations (Whitlock 2003). Yet, 32 of the 42 responding communities maintained the London plane tree on their approved planting lists. Similar concerns exist for oaks (Quercus spp.), which are notorious for interbreeding within subgenera.

\section{Patterns and Trends of Diversity Within California Communities}

The size of the inventories and approved planting lists suggest that diversity is well-represented within individual communities of California (Table 1). However, as might be anticipated, most of the inventories were concentrated on a small subset of the overall composition. For instance, in the community with the number of inventory species closest to the average (176), $26 \%$ of all inventoried trees were accounted for by two species. The next three most abundant species accounted for an additional $20 \%$ of inventoried trees. In this same community, 49 of the inventoried species $(28 \%)$ were represented by three or fewer individuals, a particularly low number considering potential threats from drought, disease, or development. If those few individuals were planted in close proximity, which is often the case, the susceptibility to any of these threats is further increased. Lesser (1996) found that 15 species accounted for approximately $50 \%$ of the planted trees in southern California communities. The reality is that, within individual communities, the concentration of trees among a very few number of species is even greater. On average, among the 18 communities that provided inventory density information, half of the street trees of each community were accounted for by fewer than nine species. This concentration of trees among just a few species suggests, while the number of species found in California communities appears high, diversity is at risk. The loss of a few individuals of an under-represented species may result in the loss of a species from the community. This raises important questions in the analysis of diversity in the urban forest. How many individuals of a given species are required to be considered a viable addition to the inventory? Is risk of species loss from the inventory a viable consideration in evaluating urban forest diversity? These questions remain unanswered by those setting urban forest policy.

It is also notable that, while communities expressed a desire to maintain diversity in their urban forests, their policies may yield considerably different results. In all communities where both approved planting lists and actual inventories were available (17), almost four times as many species were already present than were approved for future planting. Thus, over the long-term, as species die and are replaced, actual diversity of a community's urban forest as measured in its inventory seems likely to decline. Given the considerably shortened life-span of trees in a street tree setting (Beatty 1991), this process of shrinking diversity may be occurring more rapidly than generally recognized. The anecdotal observations of Santa Barbara's loss of diversity are a case in point.

The number of species on the approved planting lists was unrelated to community dynamics. It was not correlated in any way to a community's size or economic well-being (but see Hope et al. 2003). Approved planting list size, however, correlated with the number of species in the actual inventory. Seemingly, a his- tory of large numbers of species in the ground is tied to a community's willingness to maintain a large number of species in future plantings. Still, in the absence of concrete steps to assure continued diversity of their urban forests, the future for all of the communities surveyed seems to be less diverse. Lesser (1996) noted a strong tendency towards planting a few favored species and similarly concluded that this would lead to a decline in diversity.

\section{Patterns and Trends of Diversity Among California Communities}

Diversity of both inventories and planting lists exhibited similar patterns among communities. Average inventories contained 185 species (range 95-408), a surprisingly robust number. However, in the composite, 632 species were represented in the inventories of one or more of the California communities surveyed. This is considerably higher than the approximately 410 species reported by Lesser (1996) in a separate survey of 21 southern California cities. The vast majority of the inventory species were found in only a few communities. Indeed, of the 18 communities providing inventory data, all listed at least one species found in no other community. Over half of the inventory species (351) were found on the streets of three or fewer communities. The approved planting lists exhibited similar patterns. Among the 42 responding communities, planting lists contained an average of 49 species (range: 12-105). However, the combined lists of the 42 communities contained 309 species. Almost two-thirds of those (198) were found in five or fewer communities (Figure 1). Conversely, 34 communities had approved species that were found on the lists of only one other community. Thus, while diversity within California communities may be considered high, it is even better-represented among communities. Similar patterns were exhibited among geographically close communities which share similar environments. For instance, eight of the communities surveyed are from the Los Angeles basin, away from the coast. Their combined inventories shared 466 species (range: 43-357). Almost $60 \%$ of these species were found on the streets of three or fewer communities. While patterns of diversity among communities may reflect, in part, the array of environments represented in California, a significant portion of that diversity reflects the unique history of each community, which has resulted in a correspondingly unique subset of species in its urban forest.

\section{Utilizing Native Species in Urban Forest Diversity}

Interest in protecting and using native species in managed landscapes continues to grow. While the question was not asked directly in this survey, one municipality described its efforts to emphasize native trees in its street tree plantings as a means to provide habitat for native wildlife. California is perhaps unique in that many of its cities are located in geographic areas that did not originally support diverse forest habitats. Consequently, the number of local native trees that can be used for street tree plantings is limited. Of the 632 species on the combined inventory lists, 44 are native to California. Of the 309 species on the combined approved planting lists, 31 are California natives. Most of these natives were poorly represented (few communities and few numbers of trees), and several of the inventory trees were of limited use in urban habitats outside of their natural range. Only a very few native species are used extensively in California urban forests, including Quercus agrifolia (on the approved 
planting lists of 25 communities), Cercis occidentalis (15), Quercus lobata (14), Calocedrus decurrens (12), Sequoia sempervirens (11), and Platanus racemosa (9). This contrasts with urban areas in the eastern United States where communities arose in locations originally covered by dense and diverse forest lands. Perhaps by necessity, early California horticulturists looked abroad for tree species suitable to the state's signature Mediterranean climate. In addition, California was heavily promoted in its early history as a land whose equable climate could grow anything. In a survey of urban forest diversity, California and Florida both exhibited significantly higher levels of diversity than 28 other states (American Forestry Association 1990), suggesting the mild temperatures and long growing seasons of both states are conducive to growth of a broad range of species.

\section{Standards for Urban Forest Diversity}

This evaluation of urban forest diversity has focused on the species richness of municipalities (i.e., the number of taxa present in the municipal forest). In this context, there are no appropriate standards that should be applied in urban forest management. The municipal forest of any community is part of a human-created environment, and its diversity will be the product of the desires of the consumers (residents, organizations, and local government agencies) as expressed in the goals and objectives of the urban forest management plan (Dwyer et al. 2003). The decision to add new species to the inventory will revolve around the desire to enhance the aesthetic beauty of the urban forest environment and to contribute to the emotional health of the community. Assuming that overall cover and health of the trees are the same, these are the attributes which differentiate the municipal forests of the communities in Table 1, and make each of these communities unique.

Some attention has been given to the appropriate concentration of species in a sustainable urban forest. At issue is avoiding over-representation of single taxa (cultivars, species, genera) in order to prevent significant loss due to unanticipated disease/pest outbreak or environmental fluctuation. Calls made to avoid overplanting have suggested limiting single species to $5 \%-15 \%$ of a community's inventory (Barker 1975; Grey and Deneke 1989; Moll 1989). More recently, this has been formalized in the 10-2030 rule (Santamour 1990; Santamour 2004), whereby no more than $10 \%$ of all individuals should come from a single species, $20 \%$ from a single genus, and $30 \%$ from a single family. This approach does not appear to be rooted in solid ecological principles, other than recognition that greater evenness of species occurrence (i.e., reduced concentration) may mitigate against devastating losses (Raupp et al. 2006). However, in an extreme case, the rule could be satisfied by no more than ten species, each of which contains $10 \%$ of the total number of individuals. Obviously, such a scenario is unlikely to happen. However, it is often the case that most trees in the urban forest come from only a few species even though they may not cross the $10 \%$ threshold. The balance, and most, of the diversity is represented by only a few individuals of each species (Lesser 1996). This lack of equity reduces the effective species diversity of the urban forest (Ricklefs and Miller 2000). The primary effect of the 10-20-30 rule is to provide a buffer against over-representation of one or more species. However, even if a single species is marginally within the $10 \%$ rule or a single genus within the $20 \%$ limit, an outbreak of disease or pest attack could leave a significant hole in a community's urban forest (Raupp et al. 2006). Furthermore, many significant diseases or pests are not limited to a single species or even genus (e.g., sudden oak death, giant white fly).

Of the 17 communities in this study that provided frequency data with their inventory species list, six contained no species with an importance of greater than $10 \%$ of the total number of trees. The remaining 11 communities contained only a single species with importance greater than $10 \%$ and five of those were below $15 \%$. In two extreme cases, communities had a single species that accounted for $23.8 \%$ and $20.1 \%$ of all inventoried trees, respectively. This planting intensity seems excessive given Arizona ash's (Fraxinus velutina) weak wood (Gilman and Watson 1993), in the first case; and crapemyrtle's (Lagerstroemia indica) susceptibility in some micro-climates to fungal leaf spot and powdery mildew (Hagan 2004), in the second.

Formulating standards for diversity of a community's urban forest may be of limited value and, further, may be a disservice. Certainly, the need to avoid over-representation of single taxa or taxonomic groups is fully justified. However, setting standards to avoid over planting may also provide communities with the false sense of their having attained as diverse an urban forest as reasonably possible. Those standards give no guidelines for under-representation of species that are important to the taxonomic diversity of a community, but are at risk of loss from lack of management, climatic extremes, or disease.

\section{CONCLUSIONS AND RECOMMENDATIONS}

The data resulting from this survey suggest several conflicting conclusions. On a statewide basis, the existing diversity of California urban forests is high. California communities lie at a unique juncture of soils, climate, and horticultural history that has led to the wide array of species successively grown there. In spite of high existing diversity, there is cause for concern about the future. Approved planting lists include only $29 \%$ of the number of trees already in the ground. Certainly, many species are inappropriate for reasons of susceptibility to disease, shallow roots, weak wood, litter, etc. However, there are multiple benefits of a diverse urban forest (Dwyer et al. 1992; Nowak and Dwyer 2007), which are important motivators in seeking new introductions to plantings in public places. The introduction of new or nontraditional species faces many obstacles (Saebo et al. 2005), not the least of which is institutional inertia because urban foresters and landscape designers understandably gravitate toward species with known attributes and proven performance records (Lesser 1996). The approved planting lists alone suggest many species already present in some California communities may be excellent candidates for other communities. Because they are already "in the ground," their qualities can be evaluated and appropriateness determined. However, this is inadequate substitution for experimentation with new, previously untested species or cultivars. The benefits of a diverse urban forest are multiple and extend beyond the functional reasons of stability (i.e., resistance to pathogens and environmental stress). A diverse urban forest contributes to the aesthetic ambiance that defines and enriches a community (Dwyer et al. 1991). That diversity also holds potential for greater understanding and appreciation of the global village that our world has become. In light of this analysis, the following steps are recommended to enhance diversity of a community's urban forest:

* Share approved planting lists among communities, and 
use trees already "in the ground" as a basis for evaluation.

* Build partnerships among local and regional groups to promote and seek out new species. In the case of this study, possible partners may include the California Urban Forests Council, the Western Chapter of the International Society of Arboriculture, the California Native Plant Society, and the California Invasive Plant Council (CalIPC).

* Build informal alliances within communities among urban foresters, landscape design professionals, regional arboreta and botanic gardens, colleges and universities, and the nursery industry.

* Identify the specific values of increased urban forest diversity to each community, and proactively build upon those values (e.g., develop educational and outreach programs to enhance public awareness).

* Build specific protocols for evaluating local invasive potential for all species on approved planting lists. In addition, evaluate inventory species with known invasive qualities.

Acknowledgments. We thank the urban foresters of the many communities who provided information for this analysis. D. Nowak and K. Knight provided valuable comment on earlier versions of the manuscript.

\section{LITERATURE CITED}

Alvey, A.A. 2006. Promoting and preserving biodiversity in the urban forest. Urban Forestry and Urban Greening 5:195-201.

Avalos, G., K. Hoell, J. Gardner, S. Anderson, and C. Lee. 2006. Impact of the invasive plant Syzigium jambos (Myrtaceae) on patterns of understory seedling abundance in a Tropical Premontane Forest, Costa Rica. International Journal of Tropical Biology 54:415-421.

American Forestry Association. 1990. 1989 Street Tree Survey of U.S. Cities and Towns. American Forestry Association, Washington, DC.

Barker, P. 1975. Ordinance control of street trees. Journal of Arboriculture 1:212-215.

Beatty, R.A. 1991. Why street trees? Pacific Horticulture 52:19-26.

Botkin, D., and L. Talbot. 1992. Biological diversity and forests, pp. 47-54. In N. P. Sharma (Ed.). Managing the world's forests: Looking for balance between conservation and development. Kendall/Hall Publishing Co., Dubuque, Iowa.

Cal-IPC. 2009. California Invasive Plant Inventory Database. Maintained by the California Invasive Plant Council. <http://www.cal-ipc.org/ip/ inventory/weedlist.php> Accessed August 26, 2009.

Chen, W.Y. and C.Y. Jim. 2008. Assessment and Valuation of the Ecosystem Services Provided by Urban Forests, pp. 53-83. In: M.M. Carreiro, Y. Song, and J. Wu (Eds.). Ecology, Planning, and Management of Urban Forests. Springer, New York.

Clark, J.R., N.P. Matheny, G.C. Cross, and V. Wake. 1997. A model of urban forest sustainability. Journal of Arboriculture 23:17-30.

Clay, J.W., and C.R. Clement. 1993. Selected species and strategies to enhance income generation from Amazonian forests. Food and Agriculture Organization of the United Nations. Working Paper FAOMisc/93/6. <http://www.fao.org/docrep/V0784E/v0784e00.HTM> Accessed 27 July, 2009.

Coppen, J.J.W. 1995. Gums, resins and latexes of plant origin. Non-Wood Forest Products, Volume 6. Food and Agriculture Organization of the United Nations. <http://www.fao.org/docrep/v9236e/v9236e00.
HTM>. Accessed September 24, 2008.

Dwyer, J.F., H.W. Schroeder, and P.H. Gobster 1991. The significance of urban trees and forests: toward a deeper understanding of values. Journal of Arboriculture 17:276-284.

Dwyer, J.F., E.G. McPherson, H.W. Schroeder, and R.A. Rowntree. 1992. Assessing the benefits and costs of the urban forest. Journal of Arboriculture 18:227-234.

Dwyer, J.F., D.J. Nowak, and M.H. Noble. 2003. Sustaining urban forests. Journal of Arboriculture 29:49-55.

Elmendorf, W. 2008. The importance of trees and nature in community: A review of the relative literature. Arboriculture \& Urban Forestry 34:152-156.

Frank, D.A., and S.J. McNaughton. 1991. Stability increases with diversity in plant communities: empirical evidence from the 1988 Yellowstone drought. Oikos 62:360-362.

Gilbert, O.L. 1991. The Ecology of Urban Habitats. Chapman \& Hall, London, UK.

Gilman, E.F., and D.G. Watson. 1993. Fraxinus velutina: Arizona Ash. Fact Sheet ST-271. Florida Cooperative Extension Service. 3 pp. $<$ http://hort.ifas.ufl.edu/trees/FRAVELA.pdf $>$ Accessed September 24, 2008.

Grey, G.W., and F.J. Deneke. 1986. Urban Forestry, Second Edition. Wiley, New York.

Hagan, A.K. 2004. Common diseases of crapemyrtle. Alabama Cooperative Extension System. ANR-1047. 4 pp.

Heidt, V., and M. Neef. 2008. Benefits of urban green space for improving urban climate, pp. 84-96. In: M.M. Carreiro, Y. Song, and J. Wu (Eds.). Ecology, Planning, and Management of Urban Forests. Springer, New York.

Heynen, N.C. 2003. The scalar production of injustice within the urban forest. Antipode 35:980-998.

Hope, D., C. Gries, W. Zhu, W.F. Fagan, C.L. Redman, N.B. Grimm, A.L. Nelson, C. Martin, and A. Kinzig. 2003. Socioeconomics drive urban plant diversity. Proceedings of the National Academy of Sciences 100:8788-8792.

Huston, M. 1979. A general hypothesis of species diversity. The American Naturalist 113:81-101.

Kaplan, S. 1995. The urban forest as a source of psychological well-being. pp. 100-108. In G. A. Bradley (Ed.). Urban Forest Landscapes: Integrating Multidisciplinary Perspectives. University of Washington Press, Seattle, WA.

Kielbaso, J.J. 2008. Management of urban forests in the United States, pp. 240-258. In: M.M. Carreiro, Y. Song, and J. Wu (Eds.). Ecology, Planning, and Management of Urban Forests. Springer, New York.

Kühn, I., R. Brandl, and S. Klotz. 2004. The flora of German cities is naturally species rich. Evolutionary Ecology Research 6:749-764.

Kuo, F. 2003. The role of arboriculture in a healthy social ecology. Journal of Arboriculture 29:148-155.

Lesser, L.M. 1996. Street tree diversity and DBH in Southern California. Journal of Arboriculture 22:180-185.

Löfvenhaft, K., C. Björn, and M. Ihse. 2002. Biotope patterns in urban areas: a conceptual model integrating biodiversity issues in spatial planning. Landscape and Urban Planning 58:223-240.

McKinney, M.L. 2002. Urbanization, biodiversity, and conservation. BioScience 52: 883-890.

McPherson, E.G., D. Nowak, G. Heisler, S. Grimmond, C. Souch, R. Grant, and R. Rowntree. 1997. Quantifying urban forest structure, function, and value: the Chicago Urban Forest Climate Project. Ur- 
ban Ecosystems 1:49-61.

Moll, G. 1989. Improving the health of the urban forest, pp. 119-130. In: G. Moll and S. Ebenreck (Eds.). A Resource Guide for Urban and Community Forests. Island Press, Washington, DC.

Muller, K.K., R.E. Broder, W. Beittel. 1974. Trees of Santa Barbara. Santa Barbara Botanic Garden, Santa Barbara, California. 248 pp.

Muller, R.N., and J.R. Haller. 2005. Trees of Santa Barbara. Santa Barbara Botanic Garden, Santa Barbara, California. 462 pp.

Nowak, D.J., and J.F. Dwyer. 2007. Understanding the benefits and costs of urban forest ecosystems, pp. 25-46. In: J.E. Kuser (Ed.). Urban and Community Forestry in the Northeast. Springer, New York.

Raupp, M.J., A.B. Cumming, and E.C. Raupp. 2006. Street tree diversity in eastern North America and its potential for tree loss to exotic borers. Arboriculture \& Urban Forestry 3:297-304.

Reichard, S.H. 1997. Prevention of invasive plant introductions on national and local levels. pp. 215-227 In: J. A. Luken and J. A. Thieret (Eds.). Assessment and Management of Plant Invasions. Springer, New York.

Reichard, S.H., and P. White. 2001. Horticulture as a Pathway of Invasive Plant Introductions in the United States. BioScience 51:103-113.

Ricklefs, R.E., and G.L. Miller. 2000. Ecology. Freeman, New York.

Saebo, A., Z. Borzan, C. Ducatillion, A. Hatzistathis, T. Lagertrom, J. Supuka, J.L. Garcia-Valdecantos, F. Rego, and J. Van Slycken. 2005. The selection of plant materials for street trees, park trees and urban woodland, pp. 257-280. In: C.C. Konijnendijk, K. Nilsson, T. B. Randrup, and J. Schipperijn (Eds.). Urban Forests and Trees. Springer-Verlag, Berlin, Germany.

Santamour, F.S. 1990.Trees for urban planting: Diversity, Uniformity and Common Sense. Proceedings, 7th Conference Metropolitan Tree Improvement Alliance (METRIA), pp. 57-65.

Santamour, F.S. 2004. Trees for urban planting: diversity, uniformity, and common sense, pp. 396-399. In: C.R. Elevitch (Ed.). The Overstory Book: Cultivating Connections with Trees. Permanent Agriculture Resources, Holualoa, Hawaii.

Schulze, E.D., and H.A. Mooney. 1993. Biodiversity and Ecosystem Function. Ecological Studies 99. Springer-Verlag, Berlin, Germany. $525 \mathrm{pp}$.

Sullivan, W.C., and F.E. Kuo. 1996. Do trees strengthen urban communities, reduce domestic violence? USDA Forest Service. Forestry Report R8-FR 56. 4 pp.

Tyrväinen, L., and A. Miettinen. 2000. Property prices and urban forest amenities. Journal of Environmental Economics and Management 39:205-223.
Ulrich, R.S. 1979. Visual landscapes and psychological well-being. Landscape Research 4:17-23.

Ulrich, R.S, 1984. View through a window may influence recovery from surgery. Science 224:420-421.

Ulrich, R.S., R.F. Simons, B.D. Losito, E. Fiorito, M.A. Miles, and M. Zelson. 1991. Stress recovery during exposure to natural and urban environments. Journal of Environmental Psychology 11:201-230.

U.S. Census Bureau. 2008. Quick Facts. <http://quickfacts.census.gov/ qfd/states/06000.html> Accessed October 2, 2008.

Wania, A., I. Kühn, and S. Klotz. 2004. Plant richness patterns in agricultural and urban landscapes in central Germany-spatial gradients of species richness. Landscape and Urban Planning 75:97-110.

Whitlock, D.L. 2003. The hybridization of California sycamore (Platanus racemosa) and the London plane tree (Platanus $\times$ acerifolia) in California's riparian woodland. Thesis. California State University, Chico. 40 pp.

Willis, K.J., and R.J. Whittaker. 2002. Species diversity - scale matters. Science 295:1245-1248.

Zipperer, W.C. 2008. Applying Ecosystem Management to Urban Forestry, pp. 97-108. In: M.M. Carreiro, Y. Song, and J. Wu (Eds.). Ecology, Planning, and Management of Urban Forests. Springer, New York.

Robert N. Muller (corresponding author)

Director of Research

Santa Barbara Botanic Garden

1212 Mission Canyon Road

Santa Barbara, CA 93105

rmuller@sbbg.org

Carol Bornstein

Horticulturist

2217 Oak Park Lane

Santa Barbara, CA 93105

caroljb@verizon.net

Résumé. Les politiques pour promouvoir la diversité de la forêt urbaine ont fait l'objet d'une étude parmi 49 villes de la Californie au moyen d'un court questionnaire suivi d'une évaluation des inventaires 
d'arbres de rues et des listes approuvées de plantation. Alors que la majorité des répondants (82\%) indiquaient que le maintien d'une diversité en espèces était un objectif dans leur gestion de la forêt municipale, moins de la moitié $(48 \%)$ de celles qui avaient répondu positivement à cette question avaient codifié cet objectif dans leur plan de gestion de la forêt urbaine. La protection contre l'invasion par les parasites était un objectif d'une minorité des communautés $(24 \%)$. Les inventaires d'arbres de rues, fournies par 28 répondants, démontraient une diversité existante élevée au sein des communautés de l'état de la Californie (moyenne de 185 espèces par communauté, variation de 95 à 408 espèces différentes). Dans les villes où les inventaires d'arbres et les listes approuvées de plantation pouvaient être comparés directement, le nombre d'espèces approuvées pour de futures plantations était de $29 \%$ par rapport à la quantité d'espèces présentes dans les inventaires existants. Ceci suggère que la diversité future des forêts urbaines de la Californie pourrait être à risque. Dans le but d'améliorer la diversité de leur forêt municipale, il est suggéré que les communautés retiennent une approche expérimentale pour évaluer les nouvelles espèces, construisent des collaborations productives entre les divers intervenants tout comme avec les autres communautés, et développent des opportunités pour accroître l'attention du public envers les multiples valeurs d'une forêt urbaine plus diversifiée.

Zusammenfassung. In einer Kurzumfrage, gefolgt von einer Bewertung von Baumkatastern und approbaten Pflanzlisten wurden in 49 kalifornischen Kommunen die Promotion von Artenvielfalt bei der Pflanzung abgefragt. Während die Mehrzahl der Befragten (82\%) anzeigten, dass die Erhaltung von Artenvielfalt ein zentrales Anliegen ihres Managements ist, haben weniger als die Hälfte dieser Befragtengruppe (48\%) dieses Anliegen in ihrem Managementplan kodifiziert. Die Schutz gegen invasive Arten war ein Anliegen bei einer Minderheit von 24\% der Befragten. Straßenbaumkataster, so sagten 18 der Befragten, verdeutlichten eine große existierende Artendiversität innerhalb der Kommunen (durchschnittlich 185 Arten/Kommune in einer Bandweite von 95-408 Arten). In den Kommunen, wo Straßenbaumkataster und Pflanzlisten diekt miteinander verglichen warden konnten, betrug die Anzahl der auf- gelisteten Arten für die künftigen Pflanzungen 29\% der gegenwärtigen Artenvielfalt. Das lässt darauf schließen, daß die zukünftige Artenvielfalt in Kalifornien gefährdet ist. Im Bemühen, die Vielfalt der urbanen Pflanzungen zu erhalten, wird empfohlen, daß die Kommunen eine Bewertung von neuen Arten in Testverfahren beibehält, productive Zusammenarbeit der verschiedenen Interessensgruppen und Kommunen fördert und Maßnahmen ergreift, die Öffentlichkeit mehr über den Wert und die Vorteile von Artenvielfalt zu informieren.

Resumen. Se evaluaron las políticas para promover la diversidad del bosque urbano en 49 municipalidades de California, U. S. a través de un cuestionario, seguido por inventarios de evaluación de árboles urbanos y listas de plantación aprobados. Mientras que la mayoría de encuestados $(82 \%)$ indicaron que la diversidad de especies fue un objetivo en el manejo de su bosque municipal, poco menos de la mitad (48\%) respondió que había codificado el objetivo en el plan de manejo del bosque urbano. La protección contra especies invasivas fue un objetivo para una minoría de comunidades (24\%). Los inventarios de árboles urbanos, proporcionados por 18 encuestados, indicaron una alta diversidad existente dentro de las comunidades del estado de California (en promedio 185 especies por comunidad; variando de 95-408). En comunidades donde ambos, inventarios y lista de plantas, pudieron ser comparados directamente, el número de especies aprobado para futuras plantaciones fue $29 \%$ del número de especies en el inventario existente. Esto sugiere que la diversidad futura de los bosques urbanos de California puede estar en riesgo. Con el fin de mejorar la diversidad de sus bosques municipales se sugiere que las comunidades conserven una aproximación experimental para evaluar nuevas especies, construir oportunidades productivas con todos los propietarios como también con otras comunidades, y desarrollar oportunidades para realzar la conciencia pública de los múltiples valores de un bosque urbano diverso. 


\section{APPENDIX. SURVEY QUESTIONNAIRE TO DETERMINE POLICIES AND PRACTICES REGARDING DIVERSITY OF} MUNICIPAL FORESTS IN CALIFORNIA, U.S. COMMUNITIES. ${ }^{7}$

Does your municipality have a goal to diversify its tree population? Yes No

If yes, do you have a formal plan for accomplishing this goal? Yes No

If you have a plan in place, who participated in developing the plan? (titles and affiliations, not individual names)

Briefly describe the plan.

Does the plan address potentially invasive exotic species? Yes No

If yes, please explain.

Does your municipality maintain a current inventory of tree species planted in parks and along streets? Yes No

If yes, how often is the inventory updated?

If you have a street and park tree inventory, is it publicly available online? Yes No

If yes, what is the URL? If no, would you please send us a species list of trees in your urban forest?

Does your municipality maintain a planting list of "acceptable" trees for streets and parkways? Yes No

If yes, would you please send us a list of the approved species?

Other comments you wish to make:

Municipality

Name and title of respondent

${ }^{z}$ Formatting of the survey document included sufficient spacing to encourage full response to open-ended questions. In lieu of a formal pre-test, the survey was circulated to a group of Santa Barbara, California horticulturists, urban foresters, and growers for comment and refinement. 